\title{
AN ANALYSIS OF SPEECH ACT CLASSIFICATION IN BEAUTY AND THE BEAST
}

\author{
Diah Purwita Sintamutiani ${ }^{1}$, Dias Fitriani ${ }^{2}$, Ratih Inayah ${ }^{3}$ \\ ${ }^{1}$ IKIP Siliwangi \\ ${ }^{2}$ IKIP Siliwangi \\ ${ }^{3}$ IKIP Siliwangi \\ 11diahpurwita23@yahoo.com, ${ }^{2}$ diasfitriani19@gmail.com, ${ }^{3}$ ratih.inayah@gmail.com
}

\begin{abstract}
Pragmatics is study of significance aspects and language use which are dependent to the speaker, the addressee and other characteristics about the context of utterance. Usually people utilize language in spoken and written, for instance conversation writing ideas, thoughts and so on in the book. For example cerebration contained in fairy tale stories were poured through the writer that one may be understood by readers. These ideas are expressed in the form about speech acts as described in Yule's theory in his book Pragmatics: Speech Act Classification (1996), there are five classifications of speech act pragmatically that can be proposed with a speaker such as representatives, directives, commissives, expressives, and declarations. The researchers used Beauty and the Beast short story to be analyzed classification about speech act. The method used in this analysis is a descriptive qualitative method. The results in this study, there are 10 speech act in short story Beauty and the Beast. In the outcomes of this study, that speech act classified into 4 types. Speech act classification is mostly Directives (50\%); Representatives (30\%); Declarations (10\%); and Commissives (10\%). The classification type unfound in the story above is Expressives.
\end{abstract}

Keywords: Pragmatics, Speech Act Classification, Short Story

\section{INTRODUCTION}

Communication is the act from conveying intended meanings from one entity or group to another by means the using of symbols with semiotic rules that is understood simultaneously. In social life, we can communicate using spoken and written language. By communicating, we are as human beings can adjust to the environment. Language and humans are two things that are related to another one and cannot be separated, because language means about human communication where we can interpret the intent spoken by the talker to the opponent of speech. Humans are creatures that have the advantages to tell what they would say and feel, so that in the environment humans can interact well.

Not just in daily conversations, humans also used language in written form. Usually people often pour ideas, thoughts and so on in books. The human's written works were varied. Such as educational books, story books, poetry, songs, etc. For example, in a fairy tale, the authors have their own way of expressing the authors' idea of what the writers want to say and feel in its story.

In a fairy tale's story book, authors have their own way of expressing idea of what the writers want to say and feel in its story book. The sentence that author uses is a sentence that is easy to understand. In a story can also contain conversations and contain moral values. The ideas comprised in fairy stories were poured by writers so that could be understood by readers. 
These ideas are expressed in the form on speech acts as described in Yule's book theory of Pragmatics: Speech Act Classification (1996: 53-54), that at least five classifications speech acts pragmatically that can be proposed by the speaker such as representatives, directives, commissives, expressives, and declarations. The classification in a speech act also described in Searle's theory in his book Speech Act: A Classification of Illocutionary Acts (1976) says that "There are at least a dozen linguistically significants dimensions of differences between illocutionary acts. Of these, the most important are illocutionary point, direction of fit, and expressed psychological state. These are three form basis of a taxonomy of the fundamental classes of illocutionary acts. The five kinds basic of illocutionary acts are: representatives (or assertives), directives, commissives, expressives, and declarations.".

The language is used as an instrument for self-expression. Speakers of the language have no consideration or keep an eye out to who the audience, readers or opponents he mentioned. Moreover, language can also provide as a tools of communicating to attract the attention of others to the opponent of speech and the desire of speakers to free themselves expressing their feeling.

Fairy tale "Beauty and the Beast" is the work of Jeanne-Marie Leprince de Beaumont, and Linda Woolverton. In the story there are speeches done by the characters told in the fairy tale. The author will take a story of fairy tale with the title Beauty and the Beast by Jeanne-Marie Leprince de Beaumont, and Linda Woolverton who has some classification of its speech acts. Based on this, the author is fascinated in analyzing a fairy tales short story speech acts classifications in a study entitled "An Analysis of Speech Act Classification in Beauty and the Beast".

The researchers in this case want to present the following statements to be investigated for further study. That can be formulated as follows:

1. What are speech act classifications contained in Beauty and the Beast story?

2. What is definition and purpose of speech act classification in this story?

Then, the research objectives intend of figure out the following description.

1. Analyze and classify speech act contained in beauty and the beast short story;

2. Explains the definition and function of various speech act classifications in this story.

\section{Pragmatics}

According to Yule (1996), pragmatics is a study about contextual meaning communicated by speakers or writers, and interpreted through listeners or readers. Only pragmatics permits human into analysis: their assumptions, goals, purposes, and actions they perform while speaking. In other words pragmatics studies how people create sense of the other linguistically. Fortunately, people inclined to behave on fairly regular in a term of using language. As a part of social group we follow the expected pattern of behavior in general.

Yule (1996) has quoted that pragmatics deals with the study of meaning as communicated by a speaker or a writer and interpreted through a listener or reader. This implies that pragmatics is the study of speaker significance because it speaks more to what the talker means by saying over than what all words or phrases in the utterance mean. It also expressed that Pragmatics is a study as regards contextual meaning as they include interpretations of what a people means in particular context and how are the contexts influences that is said indirectly. Moreover, it has been an implication that Pragmatics is learning about how more acquires communicated than it said due the fact that is investigates how are listeners may appeal inferences about 
what speakers intend to say. Last but not least, Pragmatics are inquiry as regard the expression in relative distance, a meaning how is it close or distant listener, and speaker specifies how that more need to be said.

\section{Speech Act Classification}

Speech act is something expressed by someone who is not only present information, but also takes action. The speech act usually performed when offering any apologize, greeting, request, complaint, compliment, refusal, and invitation. There are several classifications for speech acts which explained by an expert. As described in Yule's theory in his book Pragmatics: Speech Act Classification (1996), generally classification system lists five kinds of general functions performed by speech acts: declarations, representatives, expressives, directives, and commissives.

Declarations are kinds as regards speech act that substitute the world by their utterance. The speaker should have a special institutional roles of specific context, so that can perform statement appropriately. By using declarations, the speaker changes the world by words.

Representatives are those types about speech acts which declare what do speaker believe to be some case or not. The statements in fact, assertions, conclusions, and descriptions are all speaker examples representing the universal as he believes it. By using a representative, the speakers make words fit to the world (on belief).

Expressives are those the categories in speech acts which can state what speakers feel. They expressed the psychological states it could be statement of pleasure, pain, likes, dislikes, joy, or sorrow. In using an expressive, a speaker make words fit the world (of feeling).

Directives are varieties of speech acts that speakers used to get someone else to do anythings. They expressed all the speaker wants. They are commands, orders, requests, and suggestions, that can be positive or negative. In use directive, a speaker would attempts to make world fit the words (via hearer).

Commissives are those classifies of a speech act that speakers apply to undertake themselves to some future actions. They states what are the speaker has intends. They are promise, threat, refusal, and pledge, they can be carried out by the talker alone, or by the speaker as component of a group. In using the commissive, the speaker performes to enact the world fit the words (via speaker).

\section{Short Story}

Short story is kind of crafted form in its own right. Mostly short stories' authors can describe their work as part of artistic and some personal expressions from the form. They can also try to reject categorize by the genre and fixed formation. Short stories have a deep roots and powers of short fiction which has been recognized in a modern society for a hundred years.

According to Maynard (2005) in Inayah (2015), defined stories as the way people communicate their experience, the way they understand the experience of others, the way they liberate their imaginations, the way they make sense of the world and their own position within it. Maynard (2005) stated that stories are important to people, politics, and education. Stories are how people make it sense of themselves and their worlds. A fairy tale or especially short story is fictional work of prose that shorter than a novel length. In contemporary fiction, short story could space from one thousand to twenty thousand words. Because of a shorter length, the short story concerns at plot, a main figure in usual (with any of additional minor characters), at one central theme, while novel can be accomplish multiple of plots and themes, with variety of prominent characters. 
Short stories also lended more of themselves to the experimentation that is using unusual prose or literary styles instruments to explain that stories. Such as uncommon styles or device might really tedious and downright annoyed in novels, but they may worked well in short stories. A short story is fiction extended by the author based on reality. Through ideas, emotion, desires and imagination to express impression of human life, short story must content itself with some character, several incident, scenes, or episodes, few setting and it happen in a brief span of time and it can develop only one or two character with anything approaching fullness. It is pressed for time (Mu'awanah, 2016).

\section{METHOD}

The method used in this analysis is a descriptive qualitative method. Shank (2002) stated qualitative research is as "a form of systematical and empirical inquiry into meaning" (p. 5). By systematic he means about "planned, ordered and public", following rules agreed upon with all members of qualitative research community. While through empirical, he intends that types of inquiries are grounded in worlds of experience. Inquiry into a meaning said the researchers tried to understand at how the others makes sense in their experiences. Some common of data collections method are applied for a question within realm of descriptive research includes a survey, interview, observation, and portfolio. Denzin and Licoln (2000) declared that qualitative researches are involves an interpretive and naturalistic approach: "It means that qualitative research is about a study things in their natural settings, attempting to make it senses or to interpret, of a phenomena in terms that the peoples meaning bring to them" (p. 3).

\section{RESULTS AND DISCUSSION}

\section{Results}

The result of analysis the sample is classifying speech act in Beauty and the Beast short story, by reason of the data has a very important position. This because the data is development of variables studied. The instrument used in collecting speech acts classification data is by collecting the data source speech act contained in the story, followed by classifying the act of speech. The results of Beauty and the Beast short story show there are 10 conversations or speech act that can be classified. The data already obtained can be directly classified into five varieties of speech act classifications, there are representatives, directives, commissives, expressives, and declarations.

Table 1. Finding of the Research

\begin{tabular}{cclc}
\hline No & Paragraph & \multicolumn{1}{c}{ Speech Act } & Speech Act Classification \\
\hline 1 & $1^{\text {st }}$ & $\begin{array}{l}\text { "Father, I only need a rose plucked by } \\
\text { your hand." }\end{array}$ & Directives \\
\hline 2 & $2^{\text {nd }}$ & $\begin{array}{l}\text { "I gave you food and a bed to sleep in! } \\
\text { And now, you are stealing my roses!" }\end{array}$ & Representatives \\
\hline 3 & $4^{\text {th }}$ & $\begin{array}{l}\text { "Look at the mirror and you can see your } \\
\text { family. Now you won't feel lonely } \\
\text { anymore." }\end{array}$ & Declarations \\
\hline
\end{tabular}




\begin{tabular}{|c|c|c|c|}
\hline 4 & $5^{\text {th }}$ & $\begin{array}{l}\text { "Please let me go home! I only want to } \\
\text { see my father before he dies!" }\end{array}$ & Directives \\
\hline 5 & $5^{\text {th }}$ & $\begin{array}{l}\text { "No! You promised you would never } \\
\text { leave this castle!" }\end{array}$ & Representatives \\
\hline 6 & $5^{\text {th }}$ & $\begin{array}{l}\text { "You may go to stay with your father for } \\
\text { seven days. But you must promise to } \\
\text { return after that." }\end{array}$ & Directives \\
\hline 7 & $5^{\text {th }}$ & "Beauty, please come back!" & Directives \\
\hline 8 & $6^{\text {th }}$ & "Please don't die, Beast!" & Directives \\
\hline 9 & $6^{\text {th }}$ & "I will live with you forever!" & Commissives \\
\hline 10 & $6^{\text {th }}$ & $\begin{array}{l}\text { "I was under a curse all these years and } \\
\text { could only be relieved when someone fell } \\
\text { in love with me. I am now cured of the } \\
\text { curse because you truly love me." }\end{array}$ & Representatives \\
\hline
\end{tabular}

\section{Discussion}

\section{Representatives}

The data included into this type is as follows:

- "I gave you food and a bed to sleep in! And now, you are stealing my roses!" In this speech act, the speaker give an assertions to the addressee.

- "No! You promised you would never leave this castle!"

In this speech act, the speaker give an assertions to the addressee.

- "I was under a curse all these years and could only be relieved when someone fell in love with me. I am now cured of the curse because you truly love me."

In this speech act, the speaker give a fact, description and conclusion to the addressee. It can be concluded that the speaker believes to be the case or not. Statements of a fact, and an assertions, descriptions, and conclusions are examples representing of the speakers in the world as he or she believes it. In using a representative, the speaker makes words fit the world (of belief).

\section{Directives}

The data included into this type is as follows:

- "Father, I only need a rose plucked by your hand."

- "Please let me go home! I only want to see my father before he dies!"

In this speech act, the speaker did a request to the addressee.

- "You may go to stay with your father for seven days. But you must promise to return after that."

In this speech act, the speaker did a suggestion and request to the addressee.

- "Beauty, please come back!"

- "Please don't die, Beast!"

In this speech act, the speaker did a command to the addresse.

It can be concluded that in directives speech act classification, the speakers used to get 
someone else to do something for instance a request, suggestion, and command. So that, the addressee possibly did what the speakers wants.

\section{Commissives}

The data included into this type is as follows:

- "I will live with you forever!"

In this speech act, the speakers used to commit themselves to several future actions. It expresses what a speaker intends. The speaker promises to addressees with the aux verb "will" in the sentence.

\section{Declarations}

The data included into this type is as follows:

- "Look at the mirror and you can see your family. Now you won't feel lonely anymore." In this speech act, the speaker changes the world via words. The speaker replaces the situation with the word that delivered to the addressee.

The results of this study, there are 10 speech act in the short story Beauty and the Beast. In the result, it can be classified into 4 types. Speech act classification is mostly Directives (50\%); Representatives (30\%); Declarations (10\%); and Commissives (10\%). The classification type unfound in speech act is Expressives.

\section{CONCLUSION}

Become a successful communicators, the individuals behoove can be understand how the different utterance forms can be vehicles of distinct communicative intentions. Among that the things which a communicators need to mastery so as may one correctly map an utterance onto intended the interpretation at least the following: firstly, the linguistic resources required to assign syntactic and semantic structures to utterances; secondly, an advanced met representational device handling by the attribution of mental states; thirdly, a systemic of social concepts involving status, authority, etc.; finally, a set of higher-order representations specifying how linguistic forms are appropriately used in specific contexts.

From the research results, the researchers can mention and describe some conclusion. The conclusion of discussion results are as follows (1) there are five categorizes on speech acts pragmatically such as representatives, directives, commissives, expressives, and declarations. (2) For the result, Beauty and the Beast short story classified into 4 types of speech act classifications, such as Directives, Representatives, Declarations, and Commissives. The most classification type found in the speech act is Directives (50\%). The classification type unfound in the speech act is Expressives.

\section{ACKNOWLEDGMENTS}

In the name of Allah the Almighty and Merciful, praise is only to Allah the lord of the worlds who blessed us with so many amazements, so the researchers could complete the article well. This journal consumed huge amount of work, research and dedication. Still, implementations would not had been possible if the researchers did not have a support of an individuals and data information. Therefore the researchers would like to extend our sinceres gratitude for all of them. The researchers are also grateful to data information that the researchers get from book, and internet. Nevertheless, the researchers express gratitude fully toward our families also colleagues for their kind co-operation and encouragement which has been help the researchers in completion the project. 


\section{REFERENCES}

Denzin, N., \& Licoln, Y. (2000). Handbook of Qualitative Research. London: Sage Publication Inc.

Inayah, R. (2015). Improving Students' Speaking Skill Through Storytelling Technique. ELTIN Journal, 3(1), 25-37.

Mu'awanah, M. H. (2016). AN ANALYSIS SPEECH ACT IN ONLINE ISLAMIC SHORT STORY “CHOOSING A WIFE AND THE LOST DIARY” BY AMINA BINT ALHUDA (Vol. 3).

Searle, J. (1976). A Classification of Illocutionary Act. California: Cambridge University Press.

Shank, G. (2002). Qualitative Research. In A Personal Skills Approach. New Jersey: Merrill Prentice Hall.

Yule, G. (1996a). Pragmatics. Oxford: Oxford University Press.

Yule, G. (1996b). Speech Act Classification. New York: Oxford University Press. 